Nippon Suisan Gakkaishi $\quad$ 70(5), 785-786 (2004)

\title{
ミニシンポジウム 頭足類学の胎動一分子解析から資源変動まで一
}

\section{頭足類の資源動態研究と頭足類学の今後}

\author{
桜 井 泰 憲 \\ 北海道大学大学院水産科学研究科
}

Present and future studies on cephalopod biology and the population dynamics

YASUNORI SAKURAI

Graduate School of Fisheries Sciences, Hokkaido University, Hakodate, Hokkaido 041-8611, Japan

世界の漁獲量は極限の平衡状態か減少傾向にあるが, この中で漁獲量が増加しつづけているのは, イカ・タコ 類を含む頭足類である。数百年もの漁業の歴史を持つ海 産魚類の資源研究とは異なり, 世界の頭足類漁業の発展 は，日本など一部の国を除けば 1950 年代からである。1) しかも，世界の頭足類漁場の開発は，スルメイカTodarodes pacificus の不漁期に展開された日本のイカ漁業の 海外進出に始まっている。そのため, 頭足類の漁獲統計 が整備されている種類は, 沿岸性イカ・タコ類を含めて 数十種のみであり，いまだに分布域や資源量の推定すら 行われていない頭足類もある。

FAO 統計（2001）によれば，1961年の世界の頭足類 漁獲量は約 75 万トンであったが， 1998 年には 380 万 トンに増加している。しかし一方では, アカイカ科（以 下スルメイカ類と略）のスルメイカとカナダイレックス Illex illecebrosus 資源は 1970-80 年代の間に急激に減少 し，スルメイカは 80 年代後半から増加したにも関わら ず，カナダイレックスは厳しい漁獲規制にも関わらず未 だに増加していない。2)さらに 2000 年以降, アルゼン チンイレックスI. argentinus の劇的な減少が新聞等で 報道されている。最近になって, 頭足類資源の変動は, 漁獲だけではなく海洋環境変化に連動していること, ま た，マグロ類やタラ類など海洋生態系の高次生物資源の 減少が，短命な頭足類，特にイカ類の急激な増加をもた らしているとの指摘がなされている。11

本シンポジウムでは,「頭足類の資源動態研究と頭足 類学の今後」という大きな課題を与えられたが，ここで はイカ類の資源動態研究に焦点を絞り, 特に著者らが飼 育実験とフィールド調查を併用して研究している気候変 化とスルメイカ資源変動に関する研究の現状と今後の方 向性について紹介する。

\section{1）イカ類の生活史と資源変動の特徵}

多くのイカ類の寿命は 1 年以内であり, 成長が早い ことである。産卵場で生まれた稚仔は 1 ミリ一数ミリと 小さく，多様な捕食者の格好な慨となる。しかし，その
後の成長は著しく，生後数ヶ月からは自分と同じ大きさ の魚類・イカ類を捕食する生物に成長する。すなわち， わずか 1 年の生活史の中で，海洋生態系食物連鎖の低 次栄養階層の「食べられる側」から，高次栄養階層の 「食べる側」へと変身できることになる。

イカ類の資源変動を考える場合，次のようなイカ類特 有の生活史戦略を念頭におく必要がある。

（1）イカ類の多くは，世代交代が 1 年単位であるた め, 親（ある年の資源）と子（翌年の資源）の関係が明 瞭である。

（2）通常は正の相関を持つ親子関係（ある年と翌年の 資源の関係）は，漁獲強度や再生産一加入過程に抢ける 環境条件の好・不適によって影響されるため, 短い年単 位での資源変動が生じやすい。例えば，ある年の資源水 準が高くても，その資源に対する過剩漁獲や再生産一加 入過程に抢ける環境の悪化があれば，翌年の資源は激減 する。また，その逆の現象も生ずる。

（3） 中長期の海洋環境のレジームシフト(寒冷一温暖) には, 世代交代が早いために資源の増減は即応的であ る。例えば, スルメイカでは, 1988/89 年の寒冷から温 暖へのレジームシフトが資源の増大を促したと推定して いる。

（4）イカ類の成長と世代交代の早さは，同じ生態系内 で共存し，慨をめぐって競争関係にある長命な魚類（イ ワシ・サバ類なぞ）の中長期の資源変動の谷間に抢い て，著しい資源増加を遂げる可能性がある。 短命なイ力類の資源変動に対する気候変化の影響は, スルメイカなど限られているが，他の長命な魚類などに 比較して, 非常に敏感に応答していると推定される。そ こで, 気候変化に応答するスルメイカ資源変動のシナリ オを以下に紹介する。

\section{2）気候変化に応答するスルメイカ資源の変動}

寿命 1 年のスルメイカは日本列島に沿って回遊し, 夏から秋に北日本周辺の海で成長し, 秋から冬に対馬海 峡や東シナ海で産卵して死亡するという生活史を毎年繰 
り返している。過去 50 年間の漁獲量は 10 万トンから 70 万トンと大きな変化をしているが, 寒冷な年が続く と資源は減少し, 温暖な年が続くと増加する傾向が認め られている。著者らは, 海洋環境の温暖・寒冷によっ て, 産卵から京化までの再生産過程の成否が決定されて いるとの作業仮説に基づいて研究を進めてきた。スルメ イカは直径 50-80 cm ほどの透明な卵塊（内部に約直径 $1 \mathrm{~mm}$ の卵が数十万個存在）を生み, 透明なゼリ一膜に 覆われた卵塊は極めて弱く, 壊れると内部の卵はバクテ リアや食害性動物プランクトンに捕食されて全滅す る。

スルメイカ資源を支えているのは秋・冬生まれ群であ り, 大不漁年が続いた 1980 年代（寒冷レジーム期）に は冬生まれ群が極端に減り, 逆に 1990 年以降の豊漁期 （温暖レジーム期）には秋・冬生まれ群がともに増加し ている。冬生まれ群の産卵場は東シナ海の大陸棚抢よび その斜面域に沿った海域である。著者らは, 長年の水槽 での産卵・人工授精実験と水中ロボットカメラによる天 然卵塊探査から,「スルメイカの産卵海域は, 水深が $100 \mathrm{~m} \sim 500 \mathrm{~m}$ の陸棚から斜面上の表層暖水内であり， 水深 $50 \mathrm{~m}$ 水温が $15 \sim 23^{\circ} \mathrm{C}$ の範囲にある」という再生 産仮説をたてた。この再生産仮説に基づいて, 秋・冬生 まれ群の産卵海域の季節・経年的変化を調べ， 80 年代 の寒冷期には冬生まれ群の産卵場は東シナ海の南の方に 偏り, 狭い海域となっており, 逆に 90 年代以降の温暖 期には, 冬の産卵場は対馬海陕まで拡大して秋の産卵場 と重なることを明らかにした。4,6)

\section{3）スルメイカ資源変動仮説の新たな提案}

なぜ, 80 年代の寒冷期に冬生まれのスルメイカが激 減してしまったのか。著者らは, 再生産海域の産卵と卵 発生に適した水温の表層暖水々中層に存在する水温（密 度）躍層に着目した。もし，スルメイカの卵塊が中層の 水温躍層付近に滞留することで大量子化に成功し, 逆に 海底まで嚁層がなく, 卵塊が海底に沈んで壊れて子化に 失敗するとすれば，冬季季節風の強さや海表面からの冷 却などによって深さが変化する季節的水温躍層の経年変 化の解明が重要となる。事実, 中層に水温躍層がなく卵 発生に適した水温の海水が海底まで達している場合に は, ふ化幼生が出現しないことが明らかとなった。つま り, 海底まで躍層がない場合には, 卵塊は海底まで沈ん で壊れてしまい, 発生途中の卵からの幼生のふ化が失敗 する可能性が高いと想定された。7) そこで, 東シナ海の 産卵場（陸棚斜面）における海上風の強さと海面気温, および冬生まれ群の漁獲量との関係を調べた。冬生まれ 群の漁獲が著しく低下した 80 年代半ばまでは, 季節風 は強く気温も低く, その後 80 年代後半からは, 風は弱 くなり気温も上昇しており, 冬生まれ群の漁獲量は, 風 が弱く, 気温が上がり始めるのを追いかけるように急激
に増加していた。豆これらのことから,「冬生まれ群の産 卵場に強風・低温が続くと資源が減少し, 弱風・高温が 続くと資源が増加する」という, 新たな再生産仮説の検 証が必要である。冬季の温暖・寒冷という気象変化は, 産卵場に打ける水温躍層の深さの季節・年変化をもたら し, 冬生まれ群のみならず, スルメイカ資源全体の再生 産過程を通した資源変動を誘導している可能性が強く示 唆される。

\section{4）おわりに}

前述したように，スルメイカの再生産過程を通した資 源変動の研究は, 新たな展開を向かえている。大気中の 風や気温という気象変化が, 海面を通して再生産海域の 水温環境, 水温躍層の深さに影響する。これらがスルメ イカの再生産一加入過程を通してどのように資源変動と 連動しているのか, 再生産海域の 3 次元的な海洋構造 の季節的・経年的変化の解析，中層から表層へと垂直に 上昇する尔化幼生の遊泳行動と水温・流れなどとの関 係, 未だに世界のスルメイカ類でも不明な初期餌料の解 明, 再生産海域加育成場・索餌成長海域への輸送・生 残過程の解明が求められる。短・中長期の気候変化に応 答するスルメイカの生活史を通した資源変動機構の解明 は，世界のイカ類資源動態研究の先導的役割を果たすも のと期待している。

\section{文献}

1) Lipinski MR, Butterworth DS, Augustyn CJ, Brodziak JKT, Christy G, Clers S, Jackson GD, O’Dor RK, Pauly D, Purchase LV, Roberts MJ, Roel BA, Sakurai Y, Sauer WHH. Cephalopod fisheries: A future global upside to past overexploitation of living marine resources? Results of an International Workshop, 31 August-2 September 1997, Cape Town, South Africa. South African Journal of Marine Science 1998; 20: 463-469.

2) Dawe EG, Colbourne EB, Drinkwater KF. Environmental effects on recruitment of short-finned squid (Illex illecebrosus). ICES Mar. Sci. 2000; 57: 1002-1013.

3） 桜井泰憲. 気候変化とイカ類資源の变動. 月刊海洋・号外 2001; 24: 228-236.

4) Sakurai $Y$, Kiyofuji $H$, Saitoh $S$, Goto $T$, Hiyama $H$. Changes in inferred spawning areas of Todarodes pacificus (Cephalopoda: Ommastrephidae) due to changing environmental conditions. ICES Mar. Sci. 2000; 57: 24-30.

5) Bower JR, Sakurai Y. Laboratory observations on Todarodes pacificus (Cephalopoda: Ommastrephidae) egg masses. Am. Malacol. Bull. 1996; 13: 65-71.

6) Sakurai Y, Kiyofuji H, Saitoh S, Yamamoto J, Goto T, Mori $\mathrm{K}$, Kinoshita T. Stock fluctuations of the Japanese common squid, Todarodes pacificus, related to recent climate changes. Fish. Sci. 2002; 68: 226-229.

7) Yamamoto J, Goto T, Sakurai Y. Does pycnocline depth affect the hatching success of Todarodes pacificus paralarvae from pelagic egg masses? ICES Mar. Sci. 2004; 61 (in press).

8）桜井泰憲, 山本 潤, 木所英昭, 森賢. 気候のレジー ムに連動したスルメイカの資源変動. 月刊海洋 2003; 35: 100-106. 